\title{
МНОГОЛЕТНЯЯ ИЗМЕНЧИВОСТЬ АНАТОМИЧЕСКИХ ПАРАМЕТРОВ ГОДИЧНЫХ КОЛЕЦ ХВОЙНЫХ ПОРОД В КРИОЛИТОЗОНЕ СРЕДНЕЙ СИБИРИ
}

\author{
(C) 2018 г. М. В. Фонти ${ }^{a, b}$ *, В. В. Фахрутдинова ${ }^{c}$, Е. В. Калинина ${ }^{b}$, И. И. Тычков ${ }^{b}$, \\ М. И. Попкова ${ }^{b}$, В. В. Шишов ${ }^{b}$, А. Н. Николаев ${ }^{d, e}$ \\ ${ }^{a}$ Институт леса им. В.Н. Сукачева СО РАН, Федеральный исследовательский центр \\ “Красноярский научный иентр СО РАН” \\ Россия, 660036 Красноярск, Академгородок, 50, стр. 28 \\ ${ }^{b}$ Сибирский федеральный университет \\ Россия, 660041 Красноярск, пр. Свободный, 79 \\ с Западно-Сибирское отделение Института леса им. В.Н. Сукачева СО РАН, \\ филиал Федерального исследовательского центра “Красноярский научный центр СО РАН" \\ Россия, 630082 Новосибирск, ул. Жуковского, 100/1 \\ ${ }^{d}$ Северо-Восточный федеральный университет им. М.К. Аммосова \\ Россия, 677000 Якутск, ул. Кулаковского, 48 \\ ${ }^{\text {e} И н с т и т у т ~ м е р з л о т о в е д е н и я ~ и м . ~ П . И . ~ М е л ь н и к о в а ~ С О ~ Р А Н ~}$ \\ Россия, 677010 Якутск, ул. Мерзлотная, 36 \\ *E-mail: mbryukhanova@mail.ru \\ Поступила в редакцию 01.06.2017 г.
}

\begin{abstract}
Проведен сравнительный анализ анатомических параметров годичных колец лиственницы Гмелина (Larix gmelinii (Rupr.) Rupr.), лиственницы Каяндера (Larix cajanderi Mayr.), сосны обыкновенной (Pinus sylvestris L.) и ели сибирской (Picea obovata Ledeb.), произрастающих в криолитозоне Средней Сибири, за период с 1960 по 2011 гг. Определены основные климатические факторы, влияющие на радиальный рост и анатомические параметры трахеид хвойных видов. Анализ анатомической структуры годичных колец является ключевым для понимания адаптивных особенностей ксилемы разных видов древесных растений в условиях климатических изменений. Это становится особенно важным для зоны распространения многолетней мерзлоты при ее возможной деградации.
\end{abstract}

Ключевые слова: ксилема, трахеиды, климатические факторы, структурно-функциональные изменения древесины, криолитозона.

DOI: $10.1134 / \mathrm{S} 0024114818050030$

В течение последних десятилетий последствия глобальных климатических изменений были зарегистрированы по всему миру (IРCC, 2013). Ожидается, что в XXI в. изменения климата будут способствовать дальнейшей модификации экосистем на структурном и функциональном уровнях (Iverson, Prasad, 2001; Tchebakova et al., 2010), сильное влияние оказывая на высокоширотные экосистемы (Serreze et al., 2000; Delisle, 2007). B результате потепления климата и изменения режима осадков ожидается, что территория криолитозоны может быть подвержена деградации вечной мерзлоты (Shur, Jorgenson, 2007; Romanovsky et al., 2008). С одной стороны, это окажет

\footnotetext{
${ }^{1}$ Работа выполнена при поддержке Российского научного фонда (14-14-00219 П) и гранта Президента Российской Федерации (МК-1589.2014.4).
}

положительное влияние на рост основных лесообразующих пород региона, так как помимо прямого влияния положительных температур почва может быть дополнительным источником доступной влаги, с другой, рост деревьев на вечной мерзлоте очень специфичен (Kujansuu et al., 2007; Николаев и др., 2011; Табакова и др., 2011), и в зависимости от локальных условий произрастания деревья могут подвергаться засухе, затоплению или испытывать недостаток питательных веществ (Lloyd, Bunn, 2007; Ohse et al., 2012).

Хвойные деревья характеризуются достаточно высокой степенью пластичности и способны адаптировать анатомическую структуру ксилемы под влиянием меняющихся условий, что дает возможность использовать анатомические параметры годичных колец для ретроспективных иссле- 
Таблица 1. Описание мест произрастания и возраст исследуемых древостоев

\begin{tabular}{l|c|c|c|l|l}
\hline Участок & Координаты участка & $\begin{array}{c}\text { Среднегодовая } \\
\text { температура воздуха, }{ }^{\circ} \mathrm{C}^{*}\end{array}$ & $\begin{array}{c}\text { Количество } \\
\text { осадков, мм/год }{ }^{1 *}\end{array}$ & Вид деревьев & Возраст, лет \\
\hline Y1LA & $\begin{array}{c}62^{\circ} 08^{\prime} \text { с.ш., } \\
128^{\circ} 39^{\prime} \text { в.д. }\end{array}$ & -10.4 & 238 & Larix cajanderi \\
SPP & $\begin{array}{l}62^{\circ} 15^{\prime} \text { с.ш., } \\
129^{\circ} 37^{\prime} \text { в.д. }\end{array}$ & -10.4 & 238 & Pinus sylvestris \\
TURA & $64^{\circ} 29^{\prime}$ с.ш., & & 370 & Larix gmelinii \\
& $100^{\circ} 35^{\prime}$ в.д. & -9.0 & Picea obovata & 110 \\
\hline
\end{tabular}

* На основе климатических данных с ближайших метеостанций “Тура” и “Якутск” за период 1960-2011 гг.

дований (Panyushkina et al., 2003; Castagneri et al., 2015; Ziaco et al., 2016). Как известно, трахеиды хвойных видов одновременно выполняют транспортную и механическую функции (Gartner, 1995; Jagels, Visscher, 2006). На фоне сложных механических и физиологических компромиссов между структурным развитием и устойчивостью к стрессам деревья формируют трахеиды с соответствующей площадью люмена и толщиной клеточной стенки (Eilmann et al., 2009; Hacura et al., 2015; Свидерская и др., 2011). Динамика именно этих показателей, а также соотношение ранней и поздней древесины в кольце представляют наибольший интерес для современных дендроклиматических исследований (Martin-Benito et al., 2013; Fonti, Babushkina, 2016; Кузьмин, Роговцев, 2016).

Недавние исследования анатомических параметров годичных колец хвойных видов деревьев криолитозоны Сибири (Бенькова В.Е., Бенькова А.В., 2006; Брюханова и др., 2014; Симанько, 2014; Bryukhanova et al., 2015) обнаружили интересные закономерности их изменчивости, обусловленные адаптивными перестройками в зависимости от региональных и локальных условий произрастания. Основываясь на принципах дендрохронологии (перекрестное датирование, чувствительность к внешним изменениям, постоянство реакции на климатические изменения), данные анатомических характеристик годичных колец (размер люмена трахеид, толщина клеточной стенки, плотность древесины) являются детализированным и достоверным источником информации о внутри- и погодичных изменениях условий среды. Такие знания представляют уникальную основу как для реконструкции, так и для прогноза изменчивости водопроводящих и механических параметров ксилемы под воздействием климатических изменений. В связи с этим изучение анатомических параметров древесины позволяет понять длительные (несколько десятков или даже сотен лет) и краткосрочные (в течение одного сезона) структурно-функциональные измене- ния ксилемы, связанные с меняющимися условиями произрастания.

В нашем исследовании на основе анализа структуры ксилемы лиственницы Гмелина, лиственницы Каяндера, ели сибирской и сосны обыкновенной из различных местообитаний в зоне сплошного распространения многолетней мерзлоты за последние 52 года роста, внимание было сосредоточено на многолетних (длительных) изменениях структурно-функциональных анатомических параметров древесины и влиянии климатических факторов на их изменчивость.

\section{ОБЪЕКТ И МЕТОДИКА}

Исследования лиственницы Гмелина (Larix gmelinii (Rupr.) Rupr.), лиственницы Каяндера (Larix cajanderi Mayr.), сосны обыкновенной (Pinus sylvestris L.) и ели сибирской (Picea obovata Ledeb.) проводились в зоне сплошного распространения многолетне-мерзлых грунтов Средней Сибири (табл. 1).

Первый участок (TURA), на котором были собраны образцы лиственницы Гмелина и ели сибирской, находится в 10 км от пос. Тура Эвенкийского района Красноярского края $\left(64^{\circ} 29^{\prime}\right.$ с.ш. $100^{\circ} 45^{\prime}$ в.д., 589 м над уровнем моря). Район расположен в области резко-континентального климата. По данным метеорологической станции пос. Тура (с 1936 по 2012 г.) среднегодовая температура воздуха составляет минус $9^{\circ} \mathrm{C}$, осадков выпадает менее 400 мм в год. Зима длится примерно 8 мес. в году, и с декабря по февраль температуры могут опускаться ниже минус $60^{\circ} \mathrm{C}$. Средняя температура самого холодного месяца в году, января, минус $35^{\circ} \mathrm{C}$. Лето короткое, с конца июня по середину августа, при этом средняя температура июля, как самого теплого месяца, составляет $17^{\circ} \mathrm{C}$. На исследуемой территории преобладают лиственничные насаждения V класса бонитета, зеленомошной группы типов леса (Абаимов и др., 1997). Участок исследования расположен на плакоре, тип леса лиственничник багульниково-раз- 
нотравный, возраст деревьев около 110 лет, высота около 9 м со средним диаметром ствола $11.5 \mathrm{~cm}$. Почвы аллювиальные гумусовые, глубина деятельного слоя в августе около $60 \mathrm{~cm}$.

Климат территории Центральной Якутии, к которой приурочены два других исследуемых участка, также резко-континентальный, среднегодовая температура воздуха минус $9.8^{\circ} \mathrm{C}$, количество осадков 233 мм в год (согласно данным метеостанции "Якутск" с 1936 по 2012 г.). Средняя температура января минус $41^{\circ} \mathrm{C}$, июля $-19^{\circ} \mathrm{C}$. Участок (SPP) был выбран около научного стационара Института биологических проблем криолитозоны СО РАН “Спасская Падь” (62 $15^{\prime}$ с.ш., $129^{\circ} 37^{\prime}$ в.д., 220 м над уровнем моря) в 25 км к северо-востоку от Якутска. Здесь преобладает сосняк толокнянково-брусничной группы типов леса. Почвы супесчаные оподзоленные, с нормальной степенью дренированности, максимальная глубина деятельного слоя почвы 50 см. На данном участке были собраны образцы сосны обыкновенной содоминантных деревьев возрастом около 218 лет, высотой 20 м, диаметром ствола на высоте груди $26 \mathrm{cm.}$

Участок (Y1LA) с координатами $62^{\circ} 08^{\prime}$ с.ш., $128^{\circ} 39^{\prime}$ в.д., 230 м над уровнем моря расположен на расстоянии 60 км в западном направлении от Якутска и представлен преимущественно лиственничными насаждениями с развитым подлеском голубично-зеленомошной группы типов леса. Тип почвы - мерзлотно-таежный палевый суглинистый, сезонная глубина оттаивания 50 см. Образцы лиственницы Каяндера были собраны с доминантных деревьев возрастом 199 лет, высотой 15 м и 25 см в диаметре.

Образцы древесины (керны) были взяты с 1520 деревьев каждого вида на участке возрастным буром из стволов на высоте 1.3 м от поверхности почвы. Измерения ширины годичных колец и перекрестная датировка индивидуальных серий радиального прироста деревьев проводились согласно общепринятой методике (Rinn, 1996). Статистическая проверка качества датировки проведена при помощи специализированной программы COFECHA (Holmes, 1983). На основе дендрохронологического анализа для проведения гистометрических измерений были выбраны 5-7 деревьев на каждом участке, характеризующихся наивысшими коэффициентами корреляции с мастерской хронологией $(0.60-0.80)$ и общим ходом роста в течение всех лет жизни. Каждый образец древесины (керн) размягчали кипячением в воде, затем, с помощью микротома были получены тонкие (20 мкм) поперечные срезы древесины. Окраска срезов проводилась раствором метиленового синего в течение 2-3 мин. Все клеточные характеристики препаратов древесины для пери- ода с 1960 по 2011 г. были измерены при помощи системы анализа изображений AxioScope и программного обеспечения AxioVision SE64 Rel 4.9.1 (Carl Zeiss, Германия), которое позволяет определить размеры и площади клеточных структур и просветов в разных частях годичного кольца в полуавтоматическом режиме по изображению поперечного среза древесины.

В каждом годичном кольце были выбраны 5 рядов клеток с наибольшей площадью поперечного сечения. Измерялись радиальные размеры клеток $(D)$, толщина клеточной стенки $(C W T)$, тангентальные размеры клеток $(T)$, по которым затем рассчитывались площади клеточной стенки (CWA) и люмена (LUM) (Ваганов и др., 2007). Согласно индексу Морка (Denne, 1989) на основе соотношения ширины двойной клеточной стенки и радиального размера люмена $(L D)$, в каждом кольце были установлены размеры зон ранней $(E W, 2 C W T<L D)$ и поздней $(L W, 2 C W T>L D)$ древесины, для каждой из которых были рассчитаны средние значения линейных и площадных параметров трахеид.

Плотность древесины ( $D E N)$ оценивалась как отношение площади клеточной стенки к общей площади поперечного сечения клетки (Ваганов, 1996), причем для упрощения расчетов форма клетки была принята прямоугольной:

$$
D E N=\frac{2 C W T(D+T-2 C W T)}{D T},
$$

где $D$ - радиальный размер клетки, $C W T$ - толщина клеточной стенки, $T$ - тангентальный размер клетки.

Эффективность выполнения транспортной функции (CON) оценивалась по объемной скорости потока жидкости в трахеиде (Свидерская и др., 2011). Согласно уравнению Хагена-Пуазейля объемная скорость ламинарного потока жидкости пропорциональна четвертой степени его радиуса или второй степени площади поперечного сечения. Таким образом, эффективность водопроведения $C O N$ пропорциональна второй степени радиального размера люмена $C O N=L U M^{2}$. При расчетах мы не рассматривали сопротивление концевых пор, влияющих на величину водопроведения (Sperry et al., 2006). Значения данного параметра для ранней и поздней древесины и в среднем по кольцу рассчитывались как среднее арифметическое.

Анализ влияния климатических факторов на погодичную изменчивость ширины годичных колец и анатомические параметры древесины был проведен на основе коэффициентов корреляции Пирсона между обобщенными индексными хронологиями и среднемесячными климатическими данными (количество осадков и температура воз- 
(a)

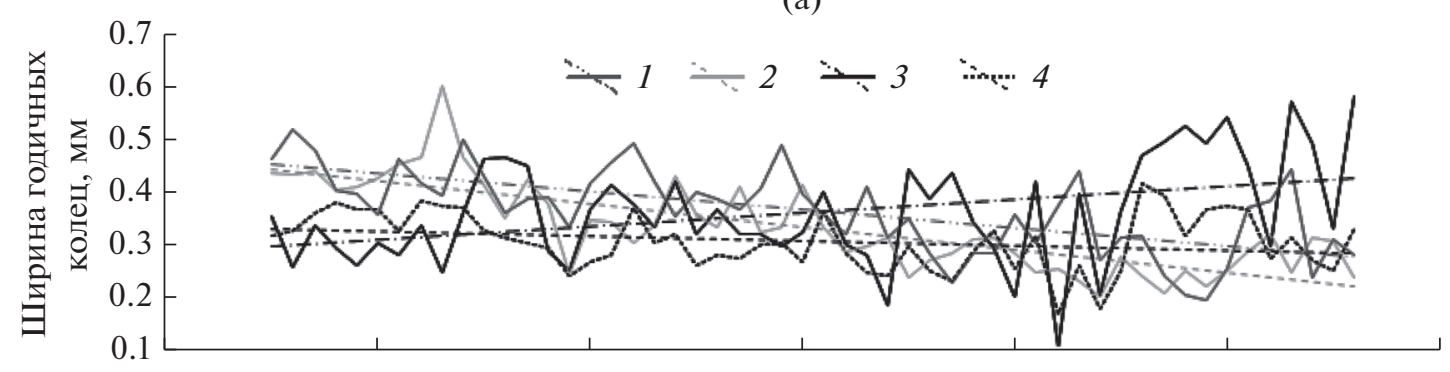

(б)
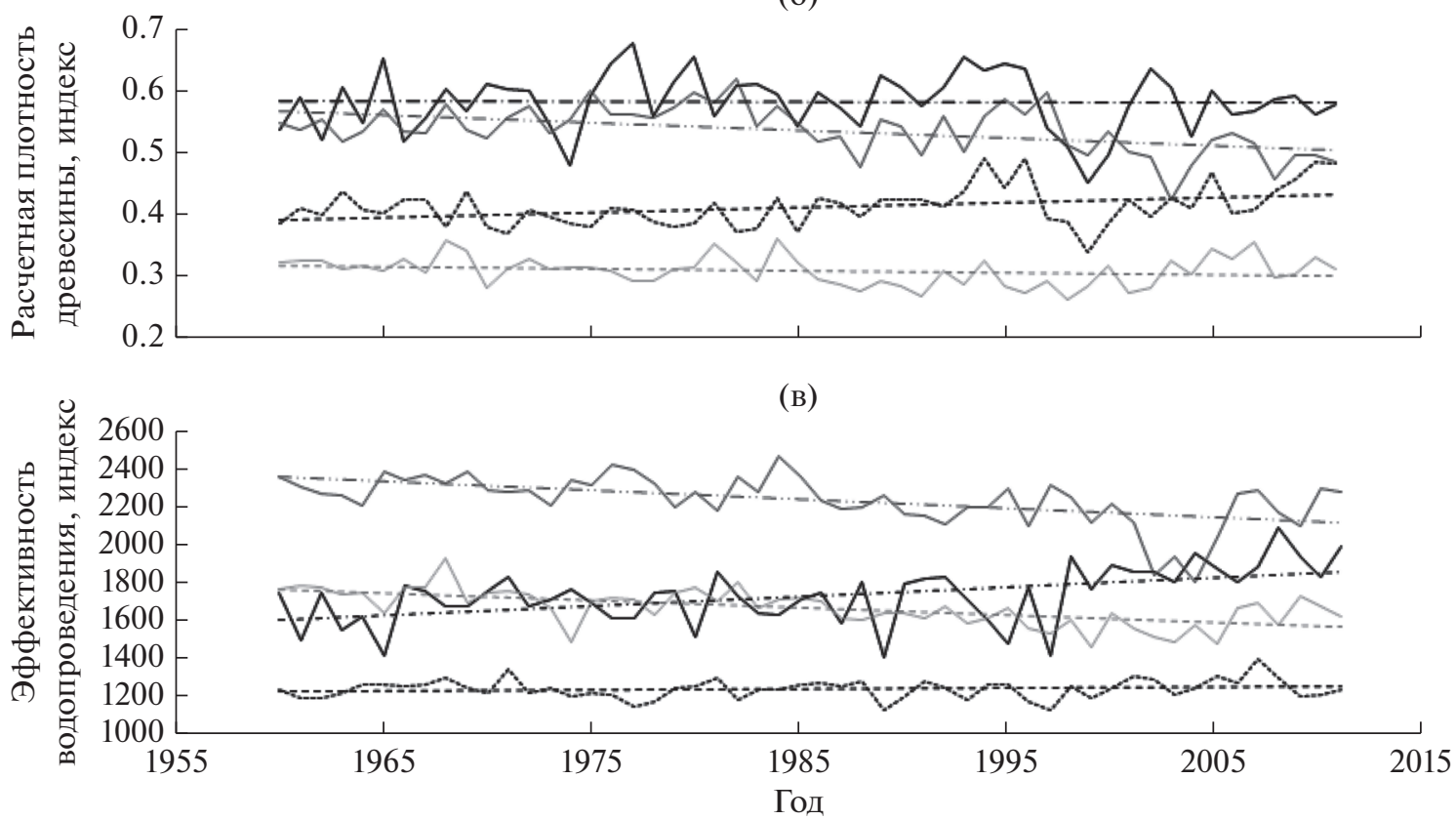

Рис. 1. Ширина годичных колец (а), расчетная плотность древесины (б) и эффективность водопроведения (в) исследуемых видов.

1 - лиственница Каяндера, Якутск; 2 - сосна обыкновенная, Спасская Падь; 3 - лиственница Гмелина, Тура; 4 - ель сибирская, Тура. Пунктирными линиями обозначены линейные тренды.

духа с ближайших метеорологических станций “Тура" и “Якутск”) для общего периода с 1960 по 2011 г. (значимая корреляция при $p<0.05$ начинается с порога 0.273).

\section{РЕЗУЛЬТАТЫ И ИХ ОБСУЖДЕНИЕ}

Анализ изменчивости радиального прироста всех видов деревьев за исследуемый период (1960-2011 г.) показал как различную погодичную динамику, так и различные тренды (рис. 1a), несмотря на схожие средние значения ширины годичных колец $(0.36 \pm 0.20$ мм для лиственницы из Эвенкии и Якутии, $0.33 \pm 0.08$ мм для сосны из Спасской Пади и $0.31 \pm 0.05$ мм для ели из Эвенкии, соответственно). Четко выраженный отрицательный тренд радиального прироста наблюдается для деревьев лиственницы и сосны из Якутии, в то время как для ели из Эвенкии не было обнаружено значимых изменений, а для лиственницы с того же участка наблюдается увеличение прироста, особенно в течение последнего десятилетия. Результаты сравнения радиального прироста $(T R W)$ исследуемых видов из Якутии с расчетной плотностью древесины $(D E N)$ (рис. 1а, б) показывают значимую положительную корреляцию для сосны $(R=0.52, p<0.05)$, и незначимую для лиственницы Каяндера $(R=0.13, p<0.05)$, тогда как величина эффективности водопроведения $(C O N)$ (рис. 1в) хорошо согласуется с изменениями радиального прироста для двух исследуемых видов на данной территории $(R=0.61$ и 0.57 ( $p<$ $0.05)$, для сосны и лиственницы, соответственно). При этом деревья лиственницы Гмелина и ели сибирской из Эвенкии показывают устойчивое, пусть и незначительное, повышение расчетных параметров, при которых связь эффективности водопроведения с радиальным приростом для 
(a)

Ранняя древесина

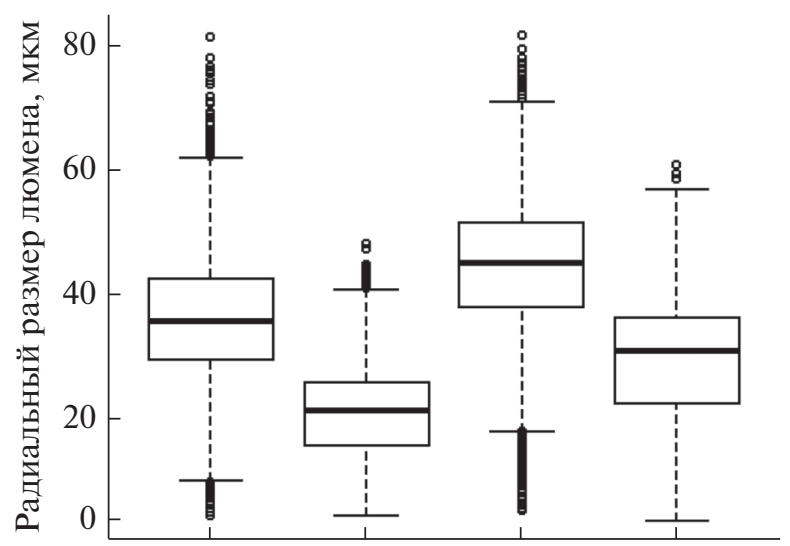

(B) (б)

Поздняя древесина

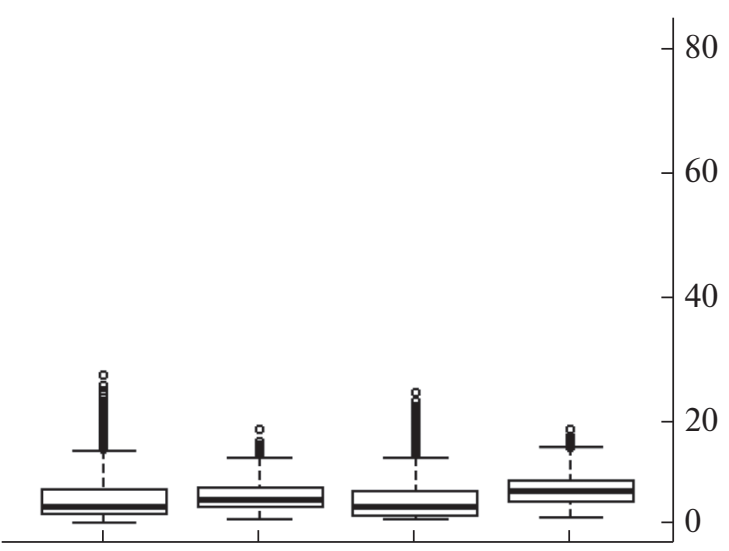

(г)
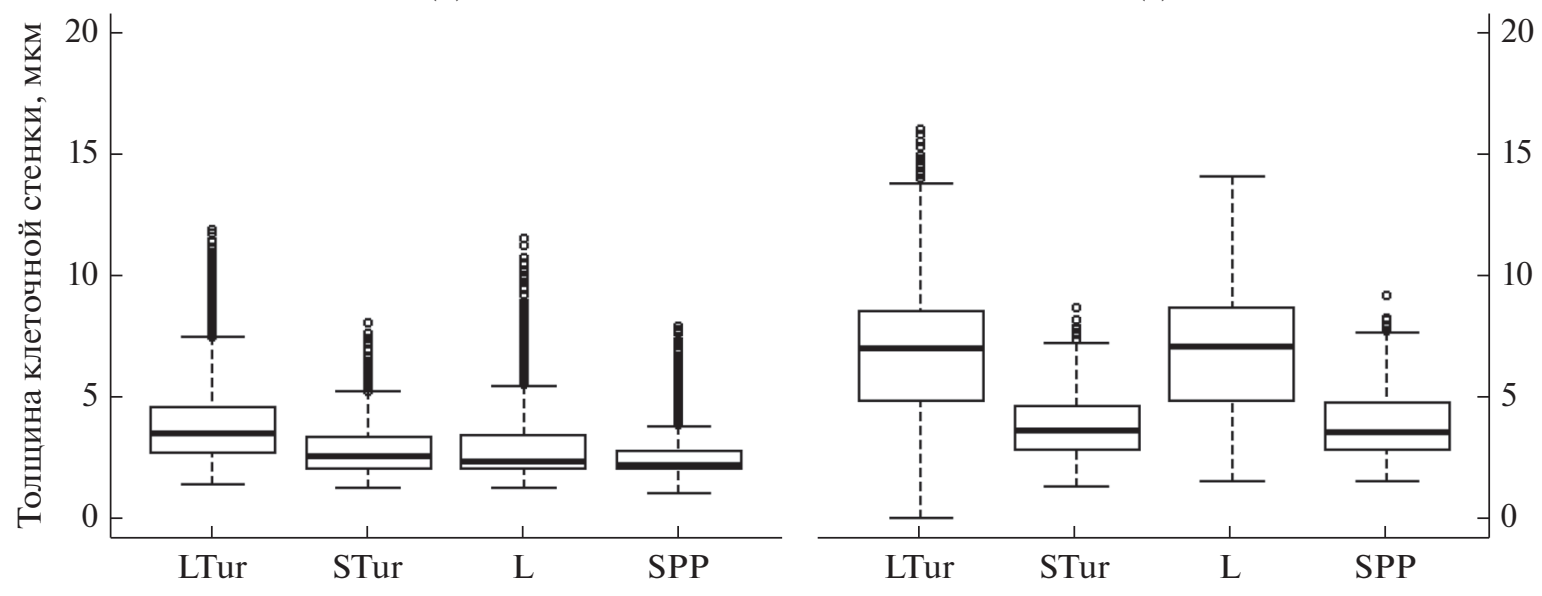

Рис. 2. Диаграмма размаха (boxplot) для радиального размера люмена (а, б) и толщины клеточной стенки трахеид (в, г) в зоне ранней и поздней древесины в годичных кольцах исследуемых видов.

LTur - лиственница Гмелина, Тура; L - лиственница Каяндера, Якутск; STur - ель сибирская, Тура; SPP - сосна обыкновенная, Спасская Падь. Линией внутри “ящика” показана медиана, размер “ящика” определен нижним и верхним квартилем (25 и 75\% выборки соответственно), “усы” - минимальное и максимальное значение выборки, точки за пределами - выбросы.

лиственницы ярко выражена $(R=0.71, p<0.05)$, а для ели незначима $(R=0.22, p<0.05)$. Незначимая положительная корреляция была получена между $D E N$ и $T R W(R=0.22$ и $0.25, p<0.05$, для лиственницы и ели, соответственно).

Рассматривая особенности анатомической структуры годичных колец разных видов хвойных криолитозоны Средней Сибири, следует отметить различия как в расчетных значениях площади клеточной стенки трахеид и площади люмена, так и в абсолютных величинах линейных параметров трехеид для зоны ранней и поздней древесины (рис. 2). Так, годичные кольца ели из Эвенкии и сосны из Спасской Пади характеризуются наименьшим размером люмена по сравнению с видами лиственницы (среднее значение \pm стандартное отклонение для ранней и поздней древе- сины: ель $-L D_{\text {ew }}=21.8 \pm 7.4$ мкм, $L D_{\text {lw }}=4.3 \pm$ \pm 2.4 мКм, сосна $-L D_{\text {ew }}=28.3 \pm 10.5 \mathrm{мKM,} L D_{\mathrm{lw}}=$ $=6.1 \pm 1.9$ мкм, соответственно). Толщина клеточной стенки также значительно меньше для вечнозеленых хвойных видов по сравнению с хвойным листопадным. В то же время следует отметить, что годичные кольца лиственницы Гмелина и Каяндера характеризуются различными размерами трахеид (например, радиальный размер люмена ранней древесины у лиственницы Гмелина в Эвенкии почти на 20\% меньше, чем у лиственницы в Якутии ( $L D_{\text {ew }}=35.9 \pm 10.1$ мкм, $L D_{\text {ew }}=44.1 \pm 11.2$ мКм, соответственно).

Корреляционный анализ измеренных и расчетных параметров годичных колец исследуемых видов в среднем по кольцу, а также для ранней и поздней древесины (рис. 3) показал, что радиаль- 
(a)

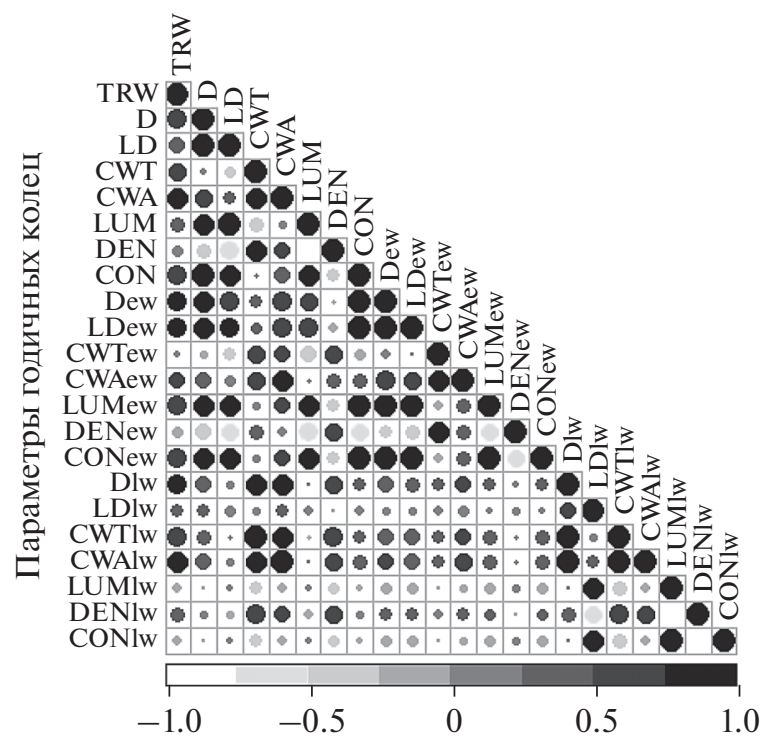

(B)

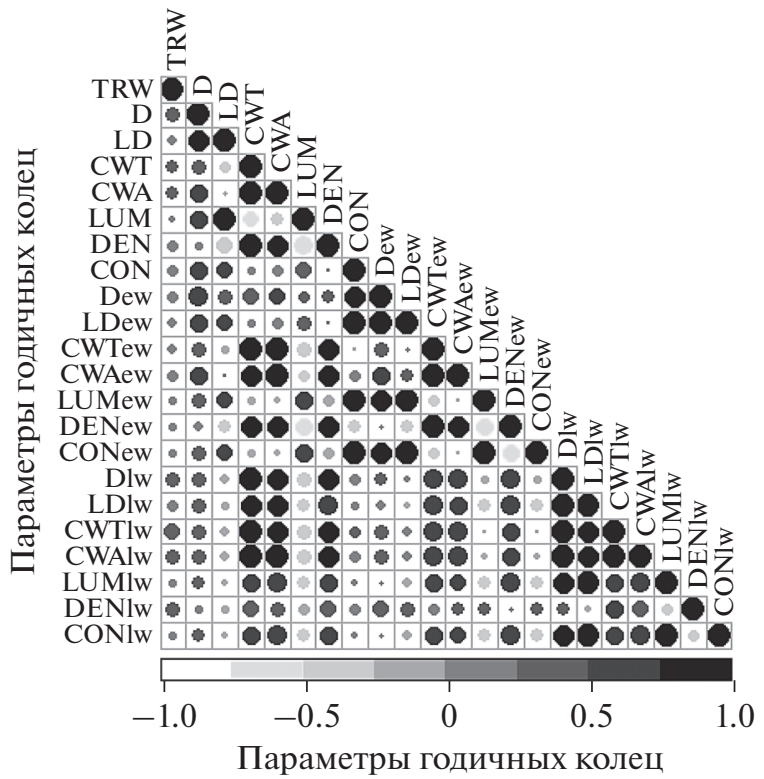

(б)

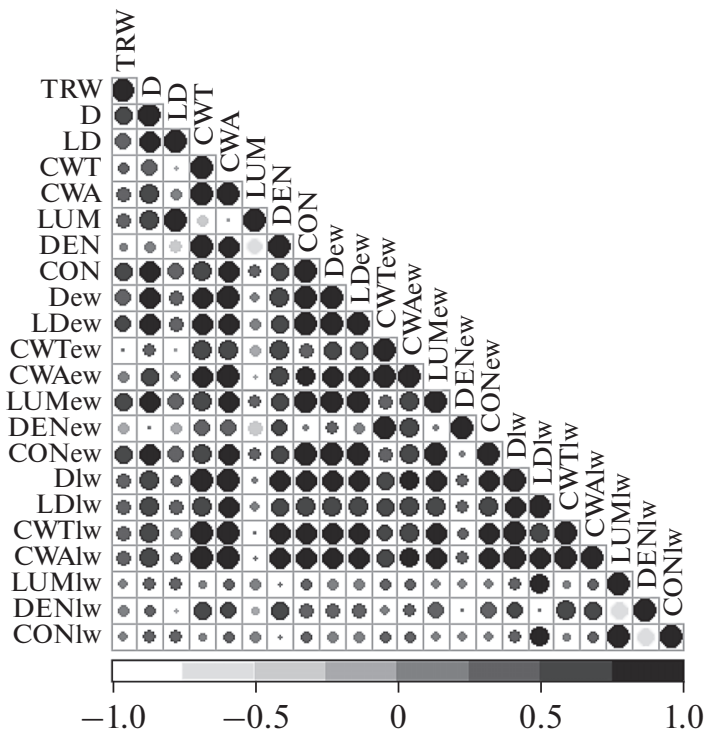

(г)

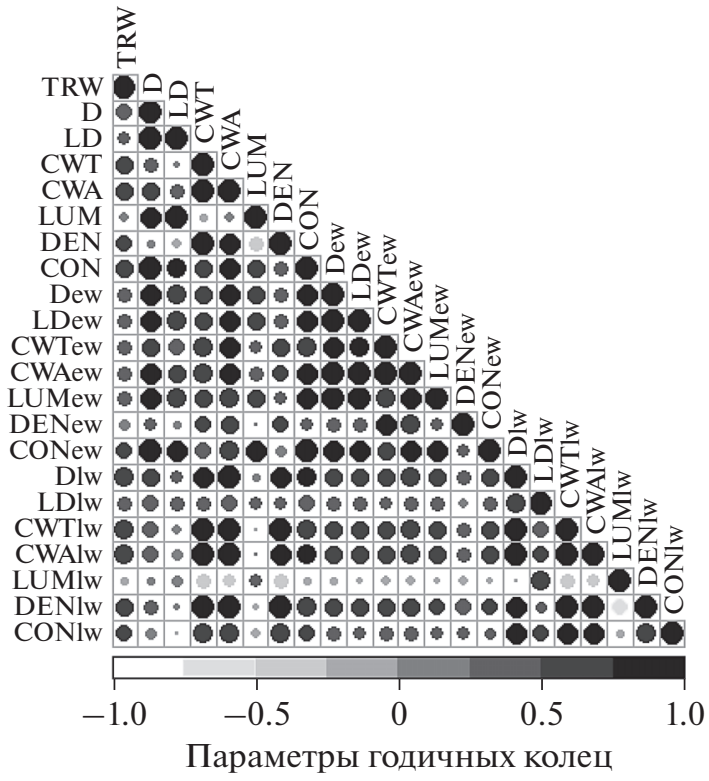

Рис. 3. Коэффициенты корреляции радиального прироста (TRW) и анатомических параметров древесины ( $D-$ радиальный размер клетки, $L D$ - радиальный размер люмена, $C W T$ - толщина клеточной стенки, $C W A-$ площадь клеточной стенки, $L U M$ - площадь люмена, $D E N$ - расчетная плотность древесины, $C O N$ - расчетная эффективность водопроведения) в среднем по кольцу и для ранней $(e w)$ и поздней $(l w)$ древесины исследуемых видов за общий период 1960-2011; а - лиственница Гмелина, Тура; б - лиственница Каяндера, Якутск; в - ель сибирская, Тура; г - сосна обыкновенная, Спасская Падь). Шкала внизу графиков - коэффициенты корреляции от -1 до 1 , значимая корреляция при $p<0.05$ начинается с порога 0.273 .

ный прирост ели наименее связан с изменениями размеров анатомических параметров трахеид (9 из 21 параметра). Отсутствие корреляции, вопервых, указывает на различные видовые особенности изменчивости роста и предполагает, что, например, при благоприятных условиях формируется большее число трахеид, влияющих на величину прироста, и при этом их линейные и пло- щадные размеры меняются слабо. Во-вторых, оно открывает возможность извлечения отличного от содержащегося в $T R W$ климатического сигнала в других параметрах годичного кольца. Для лиственницы Гмелина из Эвенкии, также как и для лиственницы Каяндера из Якутии, связь анатомических параметров и ширины годичного кольца выражена сильнее (14 параметров из 21), а 
для сосны из Спасской Пади следует отметить наивысшую корреляцию размеров трахеид с радиальным приростом (18 параметров из 21). Таким образом, при благоприятных условиях изменения ширины годичных колец происходят вместе с увеличением размеров трахеид, их люмена и толщины клеточной стенки.

Проведенный нами корреляционный анализ площадных размеров трахеид (CWA и $L U M)$ для исследуемых видов одной территории показал высокие положительные связи, что говорит о схожих структурно-функциональных изменениях, обусловленных климатическими факторами и локальными условиями произрастания. Так, например, площадь клеточной стенки ели и лиственницы из Эвенкии показывает положительную связь $R=0.47$ при $p<0.05$, такая же корреляция наблюдается и для площади люмена трахеид $(R=$ $=0.43, p<0.05)$. Для деревьев из Якутии эти корреляции составили 0.49 для $C W A$ и 0.19 для $L U M$ $(p<0.05)$, соответственно. При этом следует отметить отсутствие какой-либо значимой корреляции анатомических параметров трахеид у деревьев различных местообитаний.

Для того, чтобы выявить многолетние тренды изменчивости климатических параметров (температуры воздуха и количества осадков) для сезона роста (май-август) за период 1960-2011 гг., данные для двух районов исследования (Эвенкии и Якутии) были сопоставлены между собой. Сравнение показало как схожий характер, так и значительные различия изменчивости среднемесячных данных. Географическое положение районов исследования и изменение климатических условий с Запада на Восток Сибири обусловливают различия средней температуры воздуха и количества осадков с мая по август $\left(11.34^{\circ} \mathrm{C}\right.$ и 200.86 мм, $14.35^{\circ} \mathrm{C}$ и 128.85 мм, для Туры и Якутска, соответственно). Значительное повышение майских температур наблюдается для двух исследуемых районов, также как и рост температуры в июне, однако следует отметить повышение температуры воздуха июля для Якутска, которое не наблюдается для Туры. Количество осадков мая, июля и августа остается относительно стабильным для Якутска при некотором повышении в июне. Для Туры следует отметить положительные тренды для количества осадков в мае и августе и отрицательные в июне-июле. Корреляции между климатическими данными разных месяцев обнаружено не было.

Результаты анализа влияния климатических факторов (температуры воздуха и количества осадков) на радиальный прирост и размеры трахеид лиственницы и ели из Эвенкии за период 1960-2011 гг. показали, что температура июня оказывает положительное влияние на ширину го- дичных колец исследуемых видов (табл. 2). На радиальный прирост ели положительное влияние продолжает оказывать температура июля $(R=$ $=0.34, p<0.05)$. Значение условий этих двух месяцев на прирост деревьев полностью совпадает с полученными ранее результатами (Бенькова В.Е., Бенькова А.В., 2006), согласно которым влияние температуры на северных территориях как основного лимитирующего рост фактора не зависит от видового статуса деревьев и особенности местообитаний, а вклад других климатических факторов обусловлен локальными условиями места произрастания. Несмотря на отсутствие корреляции радиального прироста лиственницы и ели с температурой мая для общего периода, ее повышение в течение последних десяти лет стимулирует начало сезона роста в более ранние сроки и таким образом положительно влияет на ширину годичных колец $(R=0.37-0.43, p<0.05)$. Значимой корреляции между количеством осадков и радиальным приростом не обнаружено. Здесь необходимо отметить, что в расчетах использовались месячные климатические данные, при которых может быть не полностью учтено влияние короткопериодных погодных изменений. Так, при применении имитационной модели формирования годичных колец Ваганова - Шашкина (Шашкин, Ваганов, 1993; Vaganov et al., 2006) к исследуемым видам в Эвенкии (Shishov et al., 2016) с использованием суточных климатических данных авторами было обнаружено лимитирование роста лиственницы влажностью почвы в течение двух-трех недель в середине сезона роста. Такой эффект может быть вызван недостаточным количеством доступной влаги в почве, обусловленным высокими температурами воздуха и повышенной транспирацией при лимитированном количестве осадков и относительно неглубоком корнеобитаемом слое, не позволяющем использовать ресурсы при оттаивании мерзлоты. Для ели такое влияние не установлено. Это, скорее всего, обусловлено тем, что деревья ели произрастают в более влажных местообитаниях на менее дренированных почвах и не испытывают водный дефицит во время сезона роста.

Следует отметить значимые отрицательные корреляции параметров годичных колец лиственницы и ели из Эвенкии с количеством зимних осадков. Как отмечалось ранее (Ваганов и др., 1999), величина снежного покрова влияет на скорость его схода и начало сезона роста, что в свою очередь оказывает влияние на величину радиального прироста деревьев. Для ели также характерно отрицательное влияние осадков апреля (для данной территории осадки в виде снега), когда увеличение мощности снежного покрова на плохо дренируемых почвах может привести к еще 
Таблица 2. Значимые коэффициенты корреляции $(p<0.05)$ ширины годичных колец $(T R W)$, площади клеточной стенки $(C W A)$, расчетной плотности древесины $(D E N)$ и эффективности водопроведения $(C O N)$ исследуемых видов с климатическими параметрами* за период с 1960 по 2011 г.

\begin{tabular}{|c|c|c|c|c|c|c|c|c|c|c|c|c|c|}
\hline \multirow[b]{2}{*}{ Зона } & \multirow[b]{2}{*}{ Параметр } & \multicolumn{12}{|c|}{ Месяц } \\
\hline & & IX-1 & $\mathrm{X}-1$ & $\mathrm{XI}-1$ & XII-1 & $\mathrm{I}$ & II & III & IV & $\mathrm{V}$ & $\mathrm{VI}$ & VII & VIII \\
\hline & \multicolumn{13}{|c|}{ Larix gmelinii Rupr.(Rupr.), Typa } \\
\hline \multirow{4}{*}{$\sum_{2}^{\vdots}$} & $T R W$ & & & & \multirow{4}{*}{$\begin{array}{r}-0.41 \\
-0.29\end{array}$} & & & & & \multirow[b]{4}{*}{0.28} & 0.60 & & \\
\hline & $C W A$ & & & & & & & & & & $0.55 /$ & & \\
\hline & $D E N$ & & & & & & & & & & & & \\
\hline & CON & & & & & & & & & & 0.50 & & \\
\hline \multirow{3}{*}{ 党 } & $C W A$ & & & & \multirow[t]{3}{*}{-0.32} & & & & & \multirow{3}{*}{-0.30} & 0.27 & & \\
\hline & $D E N$ & & & & & & & & & & -0.31 & & \\
\hline & CON & & & & & & & & & & 0.54 & & \\
\hline \multirow{4}{*}{3} & $C W A$ & & & & \multirow{4}{*}{-0.30} & & & & & & $0.57 /$ & & \\
\hline & & & & & & & & & & & -0.29 & & \\
\hline & $D E N$ & & & & & & & & & & 0.45 & 0.48 & 0.34 \\
\hline & CON & & & & & & & & & & -0.31 & -0.52 & -0.44 \\
\hline \multirow{5}{*}{$\varliminf_{2}^{\vdots}$} & \multicolumn{13}{|c|}{ Picea obovata Ledeb., Typa } \\
\hline & $T R W$ & & & & \multirow{3}{*}{-0.33} & -0.28 & & & -0.33 & \multirow{4}{*}{0.29} & 0.56 & \multirow[t]{4}{*}{0.34} & \\
\hline & $C W A$ & & 0.32 & & & & & 0.31 & -0.30 & & 0.31 & & \\
\hline & DEN & & 0.43 & & & & & 0.31 & -0.36 & & & & \\
\hline & CON & & & & -0.33 & & & & & & & & \\
\hline \multirow{3}{*}{ 蛋 } & $C W A$ & & & & $-0.30 /$ & & \multirow[b]{3}{*}{-0.28} & \multirow{3}{*}{0.32} & & \multirow[t]{3}{*}{0.33} & & & \\
\hline & $D E N$ & & & & & & & & & & & & \\
\hline & $C O N$ & & & -0.30 & -0.28 & & & & & & & & \\
\hline \multirow{4}{*}{ ज } & $C W A$ & & 0.44 & & \multirow{4}{*}{$\begin{array}{c}-\mathbf{0 . 3 8} \\
-0.30\end{array}$} & & & 0.35 & -0.37 & & 0.33 & 0.35 & \\
\hline & $D E N$ & & & & & & & & & & 0.33 & 0.33 & \\
\hline & & & & & & & & & & & & & \\
\hline & $C O N$ & & 0.31 & & & & & 0.32 & -0.39 & & & & \\
\hline & & & & & Lari & cajande & ri Mayr. & , Якутс & & & & & \\
\hline & $T R W$ & & & & -0.29 & & & & & & & & \\
\hline 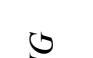 & $C W A$ & & & & & -0.37 & & -0.43 & & & $0.36 /$ & -0.38 & \\
\hline$\approx$ & $D E N$ & & & & 0.35 & & & & & & 0.34 & -0.44 & -0.30 \\
\hline & $C O N$ & & & & & & & & & & 0.32 & & \\
\hline & $C W A$ & & & -0.30 & & -0.39 & & -0.29 & & & $0.39 /$ & -0.34 & \\
\hline & & & & & & & & & & & -0.41 & & \\
\hline 国 & $D E N$ & & & -0.37 & & -0.30 & & & & & -0.44 & & \\
\hline & $C O N$ & & & & & & $-\mathbf{0 . 3 0}$ & -0.31 & & & 0.31 & & \\
\hline & $C W A$ & & & & & -0.33 & & -0.49 & & & 0.30 & -0.38 & \\
\hline 3 & $D E N$ & & & & & & & & & & & -0.41 & \\
\hline & $C O N$ & & & & & & & & & & -0.29 & & \\
\hline
\end{tabular}


Таблица 2. Окончание

\begin{tabular}{|c|c|c|c|c|c|c|c|c|c|c|c|c|c|}
\hline & & \multicolumn{12}{|c|}{ Месяц } \\
\hline \multirow[t]{2}{*}{ Зона } & Параметр & IX-1 & $\mathrm{X}-1$ & $\mathrm{XI}-1$ & $\mathrm{XII}-1$ & $\mathrm{I}$ & II & III & IV & $\mathrm{V}$ & $\mathrm{VI}$ & VII & VIII \\
\hline & \multicolumn{13}{|c|}{ Pinus sylvestris L., Спасская Падь } \\
\hline \multirow{4}{*}{$\varliminf_{2}^{\bigotimes}$} & $T R W$ & & & & & & & & & 0.29 & & & \\
\hline & $C W A$ & & & & & & -0.31 & & & & -0.28 & -0.31 & \\
\hline & $D E N$ & 0.37 & & & & & -0.32 & & & & & 0.28 & \\
\hline & CON & & & & & -0.31 & & & & & & & \\
\hline \multirow{3}{*}{$\underset{10}{\overrightarrow{1}}$} & $C W A$ & & & & & -0.31 & & & & & -0.31 & -0.29 & \\
\hline & $D E N$ & & & & & & & & & & & & \\
\hline & CON & & & & & -0.30 & & & & & & & \\
\hline \multirow{3}{*}{$\vec{z}$} & $C W A$ & & & & & & -0.29 & & & & & & \\
\hline & $D E N$ & & & & & & & & & & & & \\
\hline & CON & & & & & & & & & & & & \\
\hline
\end{tabular}

* Примечание: жирный шрифт - корреляция с температурой воздуха, обычный шрифт - корреляция с количеством осадков, пустые ячейки - незначимые при $p<0.05$ корреляции. Период расчетов - с сентября предыдущего года (IX-I) по август текушего (VIII). $R I N G$ - средние значения по кольцу, $E W$ - ранняя древесина, $L W$ - поздняя древесина.

большей обводненности в начале сезона роста и в дальнейшем лимитировать прирост данного вида.

В связи с тем, что некоторые анатомические параметры трахеид лиственницы связаны с величиной радиального прироста, их отклик на климатические факторы имеет схожий характер. Так, температура июня оказалась одним из наиболее значимых факторов, оказывающих положительное влияние не только на прирост деревьев, но и на большинство параметров трахеид (табл. 2). При этом для ранней древесины характерна обратная зависимость, когда рост температуры июня оказывает негативное влияние на плотность древесины, и положительное - на эффективность водопроведения. Т.е. при высоких температурах образуются трахеиды с большей площадью люмена и менее широкой клеточной стенкой. Разделение кольца на раннюю и позднюю древесину позволило получить дополнительную информацию о влиянии климатических факторов других месяцев на рост деревьев. Следует отметить значимую положительную корреляцию плотности поздней древесины с температурой июля и августа и отрицательную - с расчетной эффективностью водопроведения поздней древесины.

Влияние климатических условий сезона роста на прирост лиственницы Каяндера и сосны обыкновенной из Якутии уже отмечалось ранее (Николаев и др., 2011) и было частично подтверждено результатами нашего исследования (табл. 2). Анализ связи анатомических параметров годичных колец с температурой воздуха показал, что высокие температуры летних месяцев (июньиюль) оказывают отрицательное влияние на пло- щадь клеточной стенки трахеид как сосны из Спасской пади, так и лиственницы из Якутска. Повышение температур в июле-августе также негативно влияет на плотность древесины лиственницы. Такие результаты отличаются от общеизвестных (Briffa et al., 2001; Davi et al., 2003), когда повышение температуры воздуха в северных широтах способствует формированию более плотной древесины. В исследуемых нами условиях повышение летних температур при минимальном количестве осадков или даже их отсутствии вызывает водный дефицит и подавляет процессы фотосинтеза и образования ассимилятов (Bréda et al., 2006), которые в последующем могут быть использованы на построение клеточных стенок трахеид. В связи с этим количество осадков июня позволяет не только сформировать трахеиды с большим люменом для более эффективного транспорта воды, но и оказывает влияние на площадь клеточной стенки лиственницы и плотность древесины.

Для того, чтобы установить, как изменялся климатический отклик параметров годичных колец исследуемых видов на меняющиеся условия среды за период 1960-2011 гг., был применен метод “скользящих функций отклика" (Симанько и др., 2013), но для многолетнего, а не внутрисезонного интервала. При этом рассчитывали корреляцию между параметрами годичных колец для “окна" 20 лет со сдвигом 1 год (например, 19601979 гг., 1961-1980 гг., и т.д.). Всего с 1960 по 2011 г. получены корреляции для 33 периодов (значимая корреляция при $p<0.05$ начинается с порога 0.444). Представляло интерес более детально рассмотреть устойчивость климатического сигнала, 


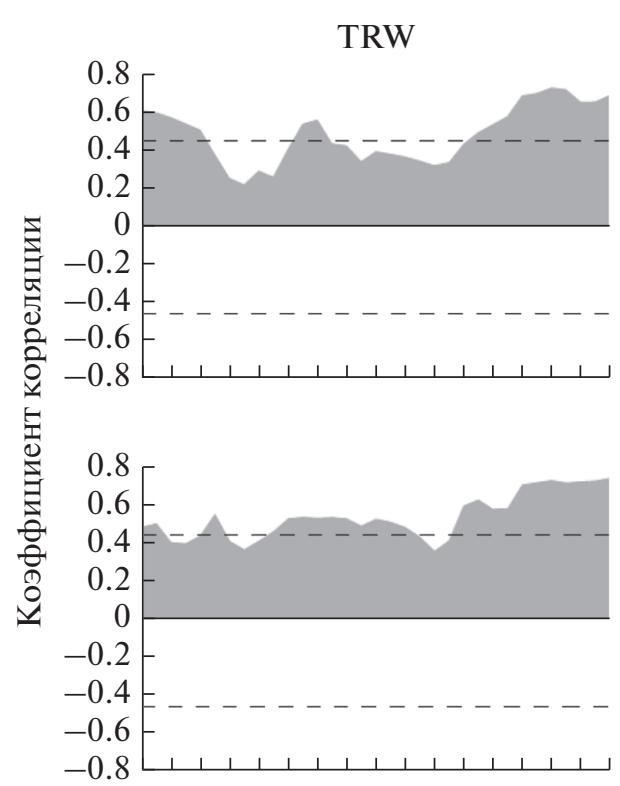

(a)

CONew

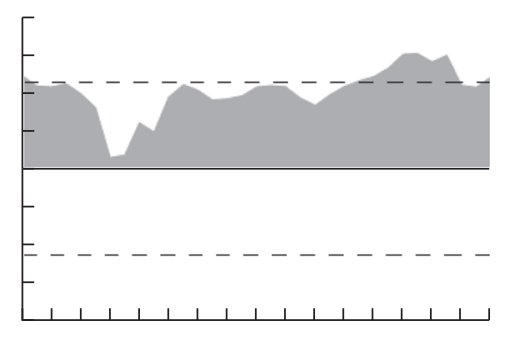

(б)
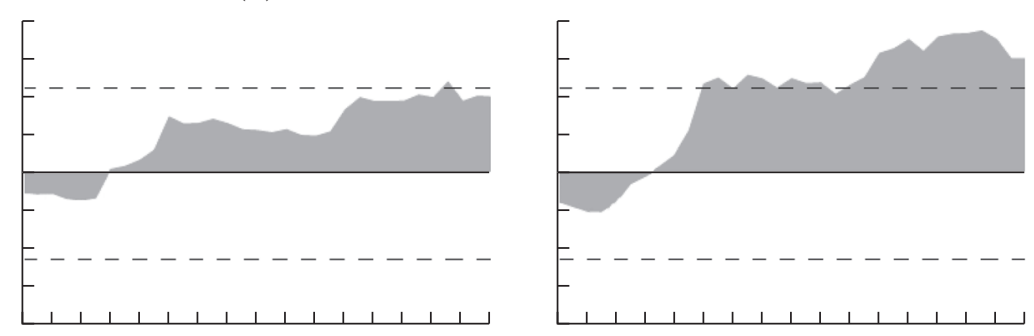

(B)
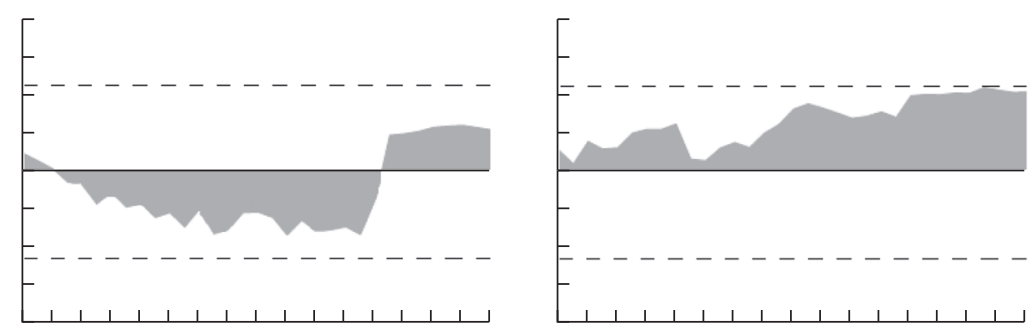

(г)

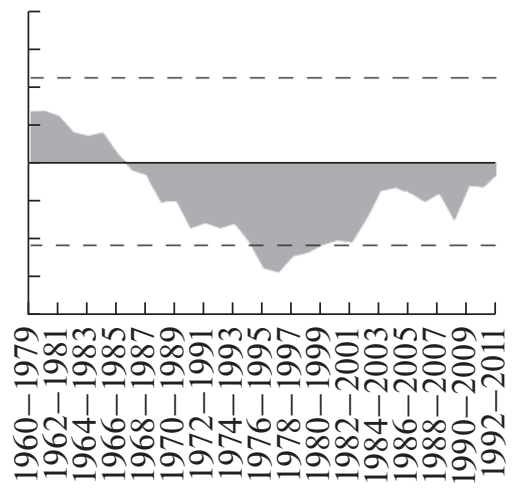

Период

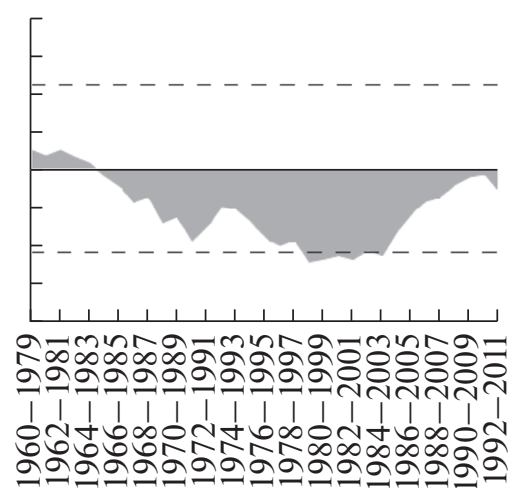

Период

Рис. 4. Скользящие коэффициенты корреляции ширины годичных колец (TRW), расчетной эффективности водопроведения ранней древесины (CONew) и плотности поздней древесины $(D E N l w)$ с температурой воздуха июня за период 1960-2011 (окно = 20 лет, шаг = 1 год).

а - лиственница Гмелина, Тура; б - ель сибирская, Тура; в - лиственница Каяндера, Якутск; г - сосна обыкновенная, Спасская Падь. Пунктирной линией обозначены критические значения коэффициентов при $p<0.05$.

зафиксированного в таких параметрах как $T R W$, $C O N$ ew и $D E N l w$. Kopреляции данных параметров с температурой воздуха июня, характеризующегося наивысшей скоростью роста хвойных видов на данной территории, показали наиболее устой- чивый сигнал для плотности поздней древесины лиственницы Гмелина из Эвенкии (рис. 4). Для ширины годичных колец и эффективности водопроведения сигнал не всегда устойчив. Схожий характер наблюдается и для корреляции парамет- 
ров ели из Эвенкии с температурой июня. При этом интересно отметить изменение влияния данного фактора на плотность поздней древесины ели в течение всего исследуемого периода с негативного на устойчивое положительное. Для лиственницы из Якутии температурный сигнал, содержащийся в рассматриваемых нами параметpax, невысокий. Следует отметить усиливающееся положительное влияние температуры июня на радиальный прирост с конца 80 -х годов прошлого века и возрастающий тренд климатического сигнала для плотности поздней древесины. Сосна из Спасской Пади характеризуется отрицательными корреляциями между температурой июня и параметрами годичных колец.

Отсутствие значимого влияния количества осадков июня на радиальный прирост и анатомические параметры лиственницы из Эвенкии подтвердилось очень низкими значениями “скользящих корреляций”. Интересно отметить рост положительной связи эффективности водопроведения с количеством осадков июня для ели из Эвенкии, и появление значимой корреляции $(p<$ $<0.05)$ с 1985. Для лиственницы из Якутии такая связь наблюдается с 1977 г. Для параметров годичных колец сосны из Спасской Пади количество осадков оказывает положительное влияние в течение всего периода 1960-2011 гг., хотя сигнал не всегда устойчив и редко достигает значимых коэффициентов корреляции.

Заключение. Данные, полученные в результате нашего исследования, показали климатически обусловленные изменения радиального прироста и анатомических параметров ксилемы годичных колец четырех исследуемых видов хвойных в зоне распространения многолетней мерзлоты за период с 1960 по 2011 г. Региональные и локальные условия произрастания и особенности гидротермического режима мерзлотных почв модифицируют влияние климатических факторов и оказывают различное влияние на радиальный рост и анатомическое строение ксилемы исследуемых видов. Так, при относительно большем по сравнению с Якутией количестве осадков и произрастании лиственницы и ели в Эвенкии на аллювиальных гумусовых почвах повышение летних температур может влиять на деградацию многолетней мерзлоты, обеспечивая деревья дополнительным источником влаги, что, в свою очередь, способствует увеличению прироста и продуктивности данных видов. Для территории Центральной Якутии повышение летних температур будет источником прогрессивно увеличивающегося стресса засухи, подавляя основные физиологические процессы роста, и, как результат, вызывая новые структурно-функциональные изменения ксилемы.

\section{СПИСОК ЛИТЕРАТУРЫ}

Абаимов А.П., Бондарев А.И., Зырянова О.А., Шитова С.А. Леса Красноярского Заполярья. Новосибирск: Наука, 1997. $208 \mathrm{c}$.

Бенькова В.Е., Бенькова А.В. Особенности строения древесины северных популяций сибирских видов лиственницы // Лесоведение. 2006. № 4. С. 28-36.

Брюханова М.В., Кирдянов А.В., Свидерская И.В., Почебыm H.П. Влияние погодных условий на анатомическую структуру годичных колец лиственницы Гмелина на севере Средней Сибири // Лесоведение. 2014. № 4. C. $36-40$.

Ваганов E.A. Механизмы и имитационная модель формирования структуры годичных колец у хвойных // Лесоведение. 1996. № 1. С. 3-15.

Ваганов Е.А., Кирдянов А.В., Силкин П.П. Значение раннелетней температуры и сроков схода снежного покрова для роста деревьев в субарктической зоне Сибири // Лесоведение. 1999. № 6. С. 3-14.

Ваганов Е.А., Скомаркова М.В., Шульце Э.-Д., Линке П. Влияние климатических факторов на прирост и плотность древесины годичных колец ели и сосны в горах Северной Италии // Лесоведение. 2007. № 2. С. 37-44. Кузьмин С.P., Роговцев Р.В. Радиальный рост и доля поздней древесины у сосны обыкновенной в географических культурах в Западной и Средней Сибири // Сибирский лесной журнал. 2016. № 6. С. 113-125.

Николаев А.Н., Федоров П.П., Десяткин А.Р. Влияние гидродинамического режима мерзлотных почв на радиальный прирост лиственницы и сосны в Центральной Якутии // Сибирский экологический журнал. 2011. № 2. С. 189-201.

Свидерская И.В., Суховольский В.Г., Радостева Е.Ю., Кирдянов $A$. $B$. Модельная оценка оптимального соотношения между толщиной клеточной стенки и размером люмена у трахеид хвойных // Журнал Сибирского федерального университета. Биология. 2011. Т. 2. № 4. C. 183-196.

Симанько B.B. Особенности радиального роста и структуры годичных колец лиственницы Гмелина на полуострове Таймыр и Котуйской возвышенности. Автореф. дис. ... канд. биол. наук (спец. 03.02.08). Красноярск: 2014. Институт леса им. В.Н. Сукачева CO РАН. $18 \mathrm{c}$.

Симанько В.В., Бенькова В.Е., Шашкин А.В. Применение метода “скользящих функций отклика" для выявления влияния климатических факторов на радиальный рост деревьев // Вестник КрасГАУ. 2013. № 7. C. $188-194$.

Табакова М.А., Кирдянов А.В., Брюханова М.В., Прокушкин А.С. Зависимость прироста лиственницы Гмелина на севере Средней Сибири от локальных условий произрастания // Журнал Сибирского федерального университета. Биология. 2011. Т. 4. № 4. С. 314-324.

Шашкин А.В., Ваганов Е.А. Имитационная модель климатической изменчивости прироста хвойных (на примере роста сосны в степной зоне) // Экология. 1993. № 5. C. 3-10.

Bréda N., Huc R., Granier A., Dreyer E. Temperate forest trees and stands under severe drought: a review of ecophys- 
iological responses, adaptation processes and long-term consequences // Annals of Forest Science. 2006. V. 63. P. 625-644.

Briffa K.R., Osborn T.J., Schweingruber H.F., Harris I.C., Jones P.D., Shiyatov S.G., Vaganov E.A. Low frequency temperature variations from a northern tree-ring density network // Journal of Geophysical Research: Atmospheres. 2001. V. 106. № D3. P. 2929-2941.

Bryukhanova M.V., Fonti P., Kirdyanov A.V., Siegwolf R.T.W., Saurer M., Pochebyt N.P., Churakova (Sidorova) O.V., Prokushkin A.S. The response of $\delta^{13} \mathrm{C}, \delta{ }^{18} \mathrm{O}$ and cell anatomy of Larix gmelinii tree rings to differing soil active layer depths // Dendrochronologia. 2015. V. 34. P. 51-59.

Castagneri D., Petit G., Carrer M. Divergent climate response on hydraulic-related xylem anatomical traits of Picea abies along a 900-m altitudinal gradient // Tree Physiology. 2015. V. 5. № 12. P. 1378-1387.

Davi N., Jacoby G., Wiles G. Boreal temperature variability inferred from maximum latewood density and tree-ring width data, Wrangell mountain region, Alaska // Quat. Res. 2003. V. 60. № 3. P. 252-262.

Delisle $G$. Near-surface permafrost degradation: how severe during the $21^{\text {st }}$ century? // Geophysical Research Letters. 2007. 34 L09503.

Denne M.P. Definition of latewood according to Mork (1928) // IAWA Bulletin. 1989. V. 10. P. 59-62.

Eilmann B., Zweifel R., Buchmann H., Fonti P., Rigling A. Drought-induced adaptation of the xylem in Scots pine and pubescent oak // Tree Physiology. 2009. V. 29. № 8. P. 1011-1020.

Fonti P., Babushkina E.A. Tracheid anatomical responses to climate in a forest-steppe in Southern Siberia // Dendrochronologia. 2016. V. 39. P. 32-41.

Gartner B. Patterns of xylem variation within a tree and their hydraulic and mechanical consequences. Plant stems: Physiology and Functional Morphology. Academic Press, San Diego, 1995. P. 125-149.

Hacura J., Gryc V., Vavrčík H., Hozová J., Urban J. The effect of drought on cell wall thickness and radial dimension of tracheids of Picea abies (L.) Karst. // Wood Research. 2015. V. 60. № 2. P. 175-188.

Holmes R.L. Computer-assisted quality control in tree-ring dating and measurement // Tree Ring Bulletin. 1983. V. 43. P. 69-78.

IPCC 2013. Climate Change 2013: The Physical Science Basis. Contribution of Working Group I to the Fifth Assessment Report of the Intergovernmental Panel on Climate Change / Eds. Stocker T.F., Qin D., Plattner G.-K., Tignor M., Allen S.K., Boschung J., Nauels A., Xia Y., Bex V., Midgley P.M. Cambridge, 2013. UK: Cambridge University Press, New York, NY, USA, 1535 p.

Iverson L.R., Prasad A.M. Potential changes in tree species richness and forest community types following climate change // Ecosystems. 2001. V. 4. № 3. P. 186-199.

Jagels S.R., Visscher G.E. A synchronous increase in hydraulic conductive capacity and mechanical support in conifers with relatively uniform xylem structure // American Journal of Botany. 2006. V. 93. № 2. P. 179-187.

Kujansuu J., Yasue K., Koike T., Abaimov A.P., Kajimoto T., Takeda T., Tokumoto M., Matsuura Y. Responses of ring widths and maximum densities of Larix gmelinii to climate on contrasting north- and south-facing slopes in central $\mathrm{Si}$ beria // Ecological Research. 2007. V. 22. № 4. P. 582-592.

Lloyd A.H., Bunn A.G. Responses of the circumpolar boreal forest to 20 th century climate variability // Environmental Research Letters. 2007. V. 2. № 4. 045013.

Martin-Benito D., Beeckman H., Cañellas I. Influence of drought on tree rings and tracheid features of Pinus nigra and Pinus sylvestris in a mesic Mediterranean forest // European Journal of Forest Research. 2013. V. 132. № 1. P. 33-45.

Ohse B., Jansen F., Wilmking M. Do limiting factors at Alaskan tree lines shift with climate regimes? // Environmental Research Letters. 2012. V.7. No. 1. 015505.

Panyushkina I.P., Hughes M.K., Vaganov E.A., Munro M.A.R. Summer temperature in northeastern Siberia since 1642 reconstructed from tracheid dimensions and cell numbers of Larix cajanderi // Canadian Journal of Forest Research. 2003. V. 33. No. 10. P. 1905-1914.

Rinn F. Tsap V 3.6 Reference manual: computer program for tree-ring analysis and presentation. 1996. Germany, Heidelberg. $263 \mathrm{p}$.

Romanovsky V.E., Kholodov A.L., Marchenko S.S., Oberman N.G., Drozdov D.S., Malkova G.V., Moskalenko N.G., Vasiliev A.A., Sergeev D.O., Zheleznyak M.N. Thermal state and fate of permafrost in Russia: First results of IPY (plenary paper) // Proceedings of the Ninth International Conference on Permafrost (eds. In: Kane D.L., Hinkel E.M.). Fairbanks, Alaska, USA: Institute of Northern Engineering, 29 June-3 July 2008. V. 2. P. 1511-1518.

Serreze M.C., Walsh J.E., Chappin III F.S., Osterkamp T., Dyurgerov M., Romanovsky V., Oechel W.C., Morison J., Zhang T., Barry R.G. Observational evidence of recent change in the northern high-latitude environment // Climatic Change. 2000. V. 46. № 1-2. P. 159-207.

Shishov V.V., Tychkov I.I., Popkova M.I., Ilyin V.A., Bryukhanova M.V., Kirdyanov A.V. VS-oscilloscope: a new tool to parameterize tree radial growth based on climate conditions // Dendrochronologia. 2016. V. 39. P. 42-50.

Shur Y.L., Jorgenson M.T. Patterns of permafrost formation and degradation in relation to climate and ecosystems // Permafrost and Periglacial Processes. 2007. V. 18. № 1. P. 7-19.

Sperry J.S., Hacke U.G., Pittermann J. Size and function in conifer tracheids and angiosperm vessels // American Journal of Botany. 2006. V. 93. P. 1490-1500.

Tchebakova N.M., Rehfeldt G., Parfenova E.I. From vegetation zones to climatypes: Effects of climate warming on $\mathrm{Si}$ berian ecosystems // Permafrost ecosystems: Siberian larch forests (eds. Osawa A., Zyryanova O.A., Matsuura Y., Kajimoto T., Wein R.W.). Ecological Studies 209. Berlin; Heidelberg; N. Y. Springer-Verlag, 2010. P. 427-446.

Vaganov E.A., Hughes M.K., Shashkin A.V. Growth Dynamics of Conifer Tree Rings: Images of Past and Future Environments. Springer-Verlag Berlin Heidelberg. 2006. 358 p.

Ziaco E., Biondi F., Heinrich I. Wood cellular dendroclimatology: testing new proxies in Great Basin Bistlecone pine // Frontiers in Plant Science. 2016. Vol. 7. P. 1602. 


\title{
Long-Term Variability of Anatomic Features of Annual Rings of Coniferous Species in Permafrost Zone in Central Siberia
}

\author{
M. V. Fonti1, 2, *, V. V. Fakhrutdinova ${ }^{3}$, E. V. Kalinina², I. I. Tychkov², \\ M. I. Popkova ${ }^{2}$, V. V. Shishov ${ }^{2}$, A. N. Nikolaev ${ }^{4,5}$ \\ ${ }^{1}$ Forest Institute, Siberian Branch of the Russian Academy of Sciences \\ Academgorodok 50 bldg. 28, Krasnoyarsk, 660036, Russia \\ ${ }^{2}$ Siberian Federal University \\ Svobodny ave. 79, Krasnoyarsk, 660041, Russia \\ ${ }^{3}$ West-Siberian Division, Forest Institute, Siberian Branch of the Russian Academy of Sciences \\ Zhukovskogo st., 100/1, Novosibirsk, 630082, Russia \\ ${ }^{4}$ North-Eastern Federal University \\ Belinsky st. 58, Yakutsk, 677027, Russia \\ ${ }^{5}$ Melnikov Permafrost Institute, Siberian Branch of the Russian Academy of Sciences \\ Merzlotnaya st. 36, Yakutsk, 677010, Russia \\ *E-mail: mbryukhanova@mail.ru \\ Received June 1, 2017
}

\begin{abstract}
Anatomic structure of annual rings is the key to understanding of adaptive specifics of xylem of various species to climate change. This is especially significant in permafrost zone due to likely permafrost degradation. We compared anatomic features of annual rings of Dahurian larch (Larix gmelinii (Rupr.) Rupr., Larix cajanderi Mayr.), Scots pine (Pinus sylvestris L.) and Siberian spruce (Picea obovata Ledeb.) growing in permafrost zone in Central Siberia for 1960-2011. Climatic factors affecting radial increment and anatomic features of tracheids of coniferous species were recognized.
\end{abstract}

Keywords: tracheids, climatic factors, structural and functional changes of xylem, permafrost zone.

Acknowledgements: this study was supported by the Russian science foundation (grant 14-14-00219 P) and the grant of the President of Russian Federation (MK-1589.2014,4).

\section{REFERENCES}

Abaimov A.P., Bondarev A.I., Zyryanova O.A., Shitova S.A., Lesa Krasnoyarskogo Zapolyar'ya (Forests of the Krasnoyarsk region above the Arctic Circle ), Novosibirsk: Nauka, 1997, $208 \mathrm{p}$.

Andrea H.L., Andrew G.B., Responses of the circumpolar boreal forest to 20th century climate variability, Environmental Research Letters, 2007, Vol. 2, No. 4, pp. 045013.

Ben'kova V.E., Ben'kova A.V., Osobennosti stroeniya drevesiny severnykh populyatsii sibirskikh vidov listvennitsy (Specifics of wood structure in northern populations of siberian species of larch), Russian Journal of Forest Science (Lesovedenie), 2006, No. 4, pp. 28-36.

Bréda N., Huc R., Granier A., Dreyer E., Temperate forest trees and stands under severe drought: a review of ecophysiological responses, adaptation processes and long-term consequences, Annals of Forest Science, 2006, Vol. 63, No. 6, pp. 625-644.

Briffa K.R., Osborn T.J., Schweingruber F.H., Harris I.C., Jones P.D., Shiyatov S.G., Vaganov E.A., Low-frequency temperature variations from a northern tree ring density network, Journal of Geophysical Research: Atmospheres, 2001, Vol. 106, No. D3, pp. 2929-2941.

Bryukhanova M.V., Fonti P., Kirdyanov A.V., Siegwolf R.T.W., Saurer M., Pochebyt N.P., Churakova O.V., Prokushkin A.S., The response of $\delta 13 \mathrm{C}, \delta 18 \mathrm{O}$ and cell anatomy of Larix gmelinii tree rings to differing soil active layer depths, Dendrochronologia, 2015, Vol. 34, pp. 51-59.

Bryukhanova M.V., Kirdyanov A.V., Sviderskaja I.V., Pochebyt N.P., Vliyanie pogodnykh uslovii na anatomicheskuyu strukturu godichnykh kolets listvennitsy Gmelina na severe Srednei Sibiri (Weather controls of the tree rings an- atomical structure of Larix gmelinii in North of Central Siberia), Russian Journal of Forest Science (Lesovedenie), 2014, No. 4, pp. 36-40.

Castagneri D., Petit G., Carrer M., Divergent climate response on hydraulic-related xylem anatomical traits of $\mathrm{Pi}$ cea abies along a 900-m altitudinal gradient, Tree Physiology, 2015, Vol. 35, No. 12, pp. 1378-1387.

Davi N.K., Jacoby G.C., Wiles G.C., Boreal temperature variability inferred from maximum latewood density and tree-ring width data, Wrangell Mountain region, Alaska, Quaternary Research, 2017, Vol. 60, No. 3, pp. 252-262.

Delisle G., Near-surface permafrost degradation: How severe during the 21st century?, Geophysical Research Letters, 2007, Vol. 34, No. 9, Article L09503.

Denne M.P., Definition of latewood according to Mork (1928), IAWA Bulletin New Series, 1988, Vol. 10, No. 1, pp. 59-62.

Eilmann B., Zweifel R., Buchmann N., Fonti P., Rigling A., Drought-induced adaptation of the xylem in Scots pine and pubescent oak, Tree Physiology, 2009, Vol. 29, No. 8, pp. 1011-1020.

Fonti P., Babushkina E.A., Tracheid anatomical responses to climate in a forest-steppe in Southern Siberia, Dendrochronologia, 2016, Vol. 39, pp. 32-41.

Gartner B., Patterns of xylem variation within a tree and their hydraulic and mechanical consequences, In: Plant stems: physiology and functional morphology San Diego: Academic Press, 1995, pp. 125-149 (460 p.).

Hacura J., Gryc V., Vavrčík H., Hozová J., Urban J., The effect of drought on cell wall thickness and radial dimension of tracheids of Picea abies (L.) Karst., Wood Research, 2015, Vol. 60, No. 2, pp. 175-188. 
Holmes R.L., Computer-assisted quality control in treering dating and measurement, Tree Ring Bulletin, 1983, Vol. 43, pp. 69-78.

Iverson L.R., Prasad A.M., Potential Changes in Tree Species Richness and Forest Community Types following Climate Change, Ecosystems, 2001, Vol. 4, No. 3, pp. 186-199. Jagels R., Visscher G.E., A synchronous increase in hydraulic conductive capacity and mechanical support in conifers with relatively uniform xylem structure, American Journal of Botany, 2006, Vol. 93, No. 2, pp. 179-187.

Kujansuu J., Yasue K., Koike T., Abaimov A.P., Kajimoto T., Takeda T., Tokumoto M., Matsuura Y., Responses of ring widths and maximum densities of Larix gmelinii to climate on contrasting north- and south-facing slopes in central Siberia, Ecological Research, 2007, Vol. 22, No. 4, pp. 582-592. Kuzmin S.R., Rogovtsev R.V., Radial'nyi rost i dolya pozdnei drevesiny u sosny obyknovennoi $\mathrm{v}$ geograficheskikh kul'turakh v Zapadnoi i Srednei Sibiri (Radial growth and percent of latewood in Scots pine provenance trials in Western and Central Siberia), Siberian Journal of Forest Science, 2016, No. 6, pp. 113-125.

Martin-Benito D., Beeckman H., Cañellas I., Influence of drought on tree rings and tracheid features of Pinus nigra and Pinus sylvestris in a mesic Mediterranean forest, European Journal of Forest Research, 2013, Vol. 132, No. 1, pp. 33-45. Nikolaev A.N., Fedorov P.P., Desyatkin A.R., Effect of hydrothermal conditions of permafrost soil on radial growth of larch and pine in Central Yakutia, Contemporary Problems of Ecology, 2011, Vol. 4, No. 2, pp. 140-149.

Ohse B., Jansen F., Wilmking M., Do limiting factors at Alaskan treelines shift with climatic regimes?, Environmental Research Letters, 2012, Vol. 7, No. 1, pp. 015505.

Panyushkina I.P., Hughes M.K., Vaganov E.A., Munro M.a.R., Summer temperature in northeastern Siberia since 1642 reconstructed from tracheid dimensions and cell numbers of Larix cajanderi, Canadian Journal of Forest Research, 2003, Vol. 33, No. 10, pp. 1905-1914.

Rinn F., TSAP V 3.6 Reference manual: computer program for tree-rings analysis and presentation, Heidelberg: Frank Rinn Distribution, 1996, 264 p.

Romanovsky V.E., Kholodov A.L., Marchenko S.S., Oberman N.G., Drozdov D.G., Malkova G.V., Moskalenko N.G., Vasiliev A.A., Sergeev D.O., Zheleznyak M.N., Thermal state and fate of permafrost in Russia: first results of IPY, Ninth International Conference on Permafrost, Fairbanks, 29 June-3 July 2008, Fairbanks, AK, USA: Institute of Northern Engineering, 2008, Vol. 2, pp. 1511-1518.

Serreze M.C., Walsh J.E., Chappin III F.S., Osterkamp T., Dyurgerov M., Romanovsky V., Oechel W.C., Morison J., Zhang T., Barry R.G., Observational Evidence of Recent Change in the Northern High-Latitude Environment, Climatic Change, 2000, Vol. 46, No. 1, pp. 159-207.

Shashkin A.V., Vaganov E.A., Imitatsionnaya model' klimaticheskoi izmenchivosti prirosta khvoinykh (na primere rosta sosny v stepnoi zone) (Simulation model of climatic variability of increment of conifers (case study of pine growth in steppe domain)), Russian Journal of Ecology, 1993, No. 5, pp. 3-10. Shishov V.V., Tychkov I.I., Popkova M.I., Ilyin V.A., Bryukhanova M.V., Kirdyanov A.V., VS-oscilloscope: A new tool to parameterize tree radial growth based on climate conditions, Dendrochronologia, 2016, Vol. 39, pp. 42-50.

Shur Y.L., Jorgenson M.T., Patterns of permafrost formation and degradation in relation to climate and ecosystems, Permafrost and Periglacial Processes, 2007, Vol. 18, No. 1, pp. 7-19. Siman'ko V.V., Osobennosti radial'nogo rosta i struktury godichnykh kolets listvennitsy Gmelina na poluostrove Taimyr $i$
Kotuiskoi vozvyshennosti. Avtoref. diss. kand. biol. nauk (Features of radial growth and annual rings structure of Dahurian larch on Taimyr peninsula and Kotuy highlands. Extended abstract of candidate's biol. sci. thesis), Krasnoyarsk: IL SO RAN, 2014, 18 p.

Simanko V.V., Benkova V.E., Shashkin A.V., Primenenie metoda "skol'zyashchikh funktsii otklika" dlya vyyavleniya vliyaniya klimaticheskikh faktorov na radial'nyi rost derev'ev (The application of "moving respons function" method for revealing climatic factor influence on tree radial growth), Vestnik Krasnoyarskogo gosudarstvennogo agrarnogo universiteta, 2013, No. 7, pp. 188-194.

Sperry J.S., Hacke U.G., Pittermann J., Size and function in conifer tracheids and angiosperm vessels, American Journal of Botany, 2006, Vol. 93, No. 10, pp. 1490-1500.

Stocker T.F., Qin D., Plattner G.-K., Tignor M.W.B., Allen S.K., Boschung J., Nauels A., Xia Y., Bex V., Midgley P.M., Climate Change 2013: The Physical Science Basis. Contribution of Working Group I to the Fifth Assessment Report of the Intergovernmental Panel on Climate Change (UK, Cambridge - USA, New York: Cambridge University Press, 2013, 1535 p.

Sviderskaya I.V., Sukhovol'skii V.G., Radosteva E.Y., Kirdyanov A.V., Model'naya otsenka optimal'nogo sootnosheniya mezhdu tolshchinoi kletochnoi stenki i razmerom lyumena $\mathrm{u}$ trakheid khvoinykh (Model Estimation of Optimal Ratio between Cell Wall Thickness and Lumen Size for Tracheids of Conifers in Temperate Zone. Journal of Siberian Federal University. Biology, 2011, Vol. 4, No. 2, pp. 183-196.

Tabakova M.A., Kirdyanov A.V., Bryukhanova M.V., Prokushkin A.S., Zavisimost' prirosta listvennitsy Gmelina na severe Srednei Sibiri ot lokal'nykh uslovii proizrastaniya (The Effect of Local Conditions on Tree-Ring Growth Dynamics of Gmelin Larch in the North of Central Siberia), Journal of Siberian Federal University. Biology, 2011, Vol. 4, No. 4, pp. 314-324.

Tchebakova N.M., Rehfeldt G., Parfenova E.I., From vegetation zones to climatypes: Effects of climate warming on Siberian ecosystems, In: Permafrost Ecosystems: Siberian Larch Forests Dordrecht: Springer Netherlands, 2010, pp. 427-446 (502 p.).

Vaganov E.A., Mekhanizmy i imitatsionnaya model' formirovaniya struktury godichnykh kolets u khvoinykh (Formation of the structure of the tree-rings of conifers: the mechanisms involved and the simulation model), Russian Journal of Forest Science (Lesovedenie), 1996, No. 1, pp. 3-15. Vaganov E.A., Hughes M.K., Shashkin A.V., Growth $d y$ namics of conifer tree rings: images of past and future environments, Berlin-Heidelberg: Springer-Verlag, 2006, 358 p.

Vaganov E.A., Kirdyanov A.V., Silkin P.P., Znachenie ranneletnei temperatury i srokov skhoda snezhnogo pokrova dlya rosta derev'ev v subarkticheskoi zone Sibiri (Contribution of early summer temperature and snow cover melting to tree growth in subarctic Siberia), Russian Journal of Forest Science (Lesovedenie), 1999, No. 6, pp. 3-14.

Vaganov E.A., Skomarkova M.V., Shulze E.-D., Linke P., Vliyanie klimaticheskikh faktorov na prirost i plotnost' drevesiny godichnykh kolets eli i sosny v gorakh Severnoi Italii (The effect of the climate factors on the increment and wood density of tree-rings of spruce and pine in the mountains of the Northern Italy), Russian Journal of Forest Science (Lesovedenie), 2007, No. 2, pp. 37-44.

Ziaco E., Biondi F., Heinrich I., Wood Cellular Dendroclimatology: Testing New Proxies in Great Basin Bristlecone Pine, Frontiers in Plant Science, 2016, Vol. 7, pp. 1602. 